\title{
Root Extract of a Micropropagated Prunus africana Medicinal Plant Induced Apoptosis in Human Prostate Cancer Cells (PC-3) via Caspase-3 Activation
}

\author{
Richard Komakech ${ }^{1 D},{ }^{1,2,3}$ Nam-Hui Yim, ${ }^{4}$ Ki-Shuk Shim, ${ }^{5}$ Haiyoung Jung, ${ }^{6,7}$ \\ Jae-Eun Byun, ${ }^{6,8}$ Jun Lee, ${ }^{1,2}$ Denis Okello, ${ }^{1,2}$ Motlalepula Gilbert Matsabisa, ${ }^{6}$ \\ Joseph O. Erhabor, ${ }^{9,10}$ Omolola Oyenihi, ${ }^{9}$ Francis Omujal, ${ }^{3}$ Moses Agwaya, ${ }^{3}$ \\ Yong-goo Kim, ${ }^{1}$ Jeong Hwan Park, ${ }^{11}$ and Youngmin Kang $\mathbb{D}^{1,2}$
}

${ }^{1}$ Herbal Medicine Resources Research Center, Korea Institute of Oriental Medicine (KIOM), 111 Geonjae-ro, Naju-si, Jeollanam-do 58245, Republic of Korea

${ }^{2}$ University of Science \& Technology (UST), Korean Convergence Medicine Major KIOM, 1672 Yuseongdae-ro, Yuseong-gu, Daejeon 34054, Republic of Korea

${ }^{3}$ Natural Chemotherapeutics Research Institute (NCRI), Ministry of Health, P.O. Box 4864, Kampala, Uganda

${ }^{4}$ Korean Medicine Application Center, Korea Institute of Oriental Medicine, 70 Cheomdan-ro, Dong-gu, Daegu 41062, Republic of Korea

${ }^{5}$ Korea Institute of Oriental Medicine (KIOM), 1672 Yuseongdae-ro, Yuseong-gu, Daejeon 34054, Republic of Korea

${ }^{6}$ Immunotherapy Research Center, Korea Research Institute of Bioscience and Biotechnology (KRIBB), 125 Gwahak-ro, Yuseong-gu, Daejeon 34141, Republic of Korea

${ }^{7}$ Department of Functional Genomics, Korea University of Science and Technology (UST), 113 Gwahak-ro, Yuseong-gu, Daejeon 34113, Republic of Korea

${ }^{8}$ Department of Biochemistry, School of Life Sciences, Chungbuk National University, Cheongju 28644, Republic of Korea

${ }^{9}$ IKS Research Group, Department of Pharmacology, Faculty of Health Sciences, University of the Free State, Bloemfontein, 9301, Free State, South Africa

${ }^{10}$ Phytomedicine Unit, Department of Plant Biology and Biotechnology, University of Benin, PMB 1154, Benin City, Nigeria

${ }^{11}$ KM Data Division, Korea Institute of Oriental Medicine (KIOM), 1672 Yuseongdae-ro, Yuseong-gu,

Daejeon 34054, Republic of Korea

Correspondence should be addressed to Youngmin Kang; ymkang@kiom.re.kr

Received 1 November 2021; Revised 14 December 2021; Accepted 7 January 2022; Published 25 January 2022

Academic Editor: Adolfo Andrade-Cetto

Copyright (C) 2022 Richard Komakech et al. This is an open access article distributed under the Creative Commons Attribution License, which permits unrestricted use, distribution, and reproduction in any medium, provided the original work is properly cited.

Prostate cancer is one of the major causes of cancer-related deaths among men globally. Medicinal plants have been explored as alternative treatment options. Herein, we assessed the in vitro cytotoxic effects of $70 \%$ ethanolic root extracts of six-month-old micropropagated Prunus africana (PIR) on PC-3 prostate cancer cells as an alternative to the traditionally used P. africana stembark extract (PWS) treatment. In vitro assays on PC-3 cells included annexin-V and propidium iodide staining, DAPI staining, and caspase- 3 activity analysis through western blotting. PC-3 cells were exposed to PWS and PIR at different concentrations, and dose-dependent antiprostate cancer effects were observed. PC-3 cell viability was determined using CCK-8 assay, which yielded $\mathrm{IC}_{50}$ values of 52.30 and $82.40 \mu \mathrm{g} / \mathrm{mL}$ for PWS and PIR, respectively. Annexin-V and PI staining showed dose-dependent apoptosis of PC-3 cells. Significant $(p<0.001)$ percent of DAPI-stained apoptotic PC-3 cells were observed in PWS, PIR, and doxorubicin treatment compared with the negative control. PWS treatment substantially elevated cleaved caspase-3 levels in PC-3 cells compared with the PIR treatment. These results provide evidence for the antiprostate cancer potential of PIR and sets a basis 
for further research to enhance future utilization of roots of young micropropagated $P$. africana for prostate cancer treatment as an alternative to stem bark. Moreover, micropropagation approach may help provide the required raw materials and hence reduce the demand for $P$. africana from endangered wild population.

\section{Introduction}

Prostate cancer is one of the most common nonskin cancers, affecting $9 \%-11 \%$ of men worldwide $[1,2]$, and one of the leading causes of cancer deaths in men [3-6]. Prostate cancer develops due to uncontrolled prostate cell division, which in turn causes abnormal cell growth and spreads to other parts of the body [1]. During the initial stages, prostate cancer is androgen-dependent, and trans-activation of target genes occurs due to androgens binding to the androgen receptor $[7,8]$. Under normal conditions and in the case of cancer androgens and androgen receptor-mediated signaling play pivotal roles in prostate functioning and development [9]. Therefore, downregulation of androgens through antiandrogenic agents is vital in prostate cancer treatment $[6,7,10]$. Typically, this cancer is treated using numerous conventional methods, including radiation therapy, surgery, hormone therapy, and cryosurgery [11]; however, these methods are frequently associated with various adverse side effects [12]. Thus, other avenues with fewer adverse effects are being continuously tested for effective treatment of prostate cancer. One such approach is the use of medicinal plants [13-15].

Many medicinal plants such as African cherry (Prunus africana (Hook f.) Kalkman; Rosaceae family) exert strong antiprostate cancer effects [9]; further, in previous ethnomedicinal studies, $P$. africana bark decoction was used to treat cancers, including prostate cancer $[1,16]$. Many scientific studies have confirmed the significant antiprostate cancer effects of $P$. africana stem bark, whereby its use as an antiprostate cancer agent has in fact already been patented [17]. In an in vivo study, transgenic adenocarcinoma of the mouse prostate (TRAMP) mice fed on P. africana (synonym Pygeum africanum) showed a significant reduction $(p=0.034)$ in prostate cancer incidence compared with casein-fed mice [18]. Similarly, in an in vitro study, the bark extract of P. africana was observed to induce about $50 \%$ growth inhibition of human prostate cancer (PC-3) and also induced significant apoptosis in the PC-3 cell line [18]. PC-3 is one of the main cell lines in in vitro studies on human prostate cancer [19].

The anticancer activity of the stem bark of $P$. africana has been attributed to numerous novel bioactive compounds, including $\beta$-sitosterol, ferulic acid, $\beta$-sitosterol-3-O-glucoside, lauric acid, oleanolic acid, ursolic acid, atraric acid, $\beta$-amyrin, and N-butylbenzene-sulfonamide $[9,20]$.

Moreover, the stem bark of $P$. africana has also been used in traditional medicine to treat several other diseases, such as benign prostatic hyperplasia, epilepsy, hemorrhage, arthritis, hypertension, and diarrhea [20, 21]. Unfortunately, the continued use of this plant constitutes a serious threat to wild populations. Indeed, the species was recently classified as an endangered species and, as such, the supply of stem bark is not sufficient to meet global demand [22]. To meet the global demand, we previously developed a micropropagation protocol for $P$. africana [23]. In this study, however, we examined the antiprostate cancer potential of the micropropagated juvenile six-month-old $P$. africana plants based on our protocol as an alternative to the use of the stem bark of wild P. africana plants using PC-3 cell line. In addition, we compared the chemical profiles of the different parts of the six-month-old plants and that of the bark of a mature wild $P$. africana plants using Fourier transform near-infrared (FT-NIR) spectrometry, gas chromatographymass spectrometry (GC-MS), and high-performance liquid chromatography (HPLC). Thus, our study provides basis for the potential use of micropropagated $P$. africana in future drug development for prostate cancer treatment.

\section{Material and Methods}

2.1. Chemicals. Analytical-grade chemicals were used for HPLC analysis, including trifluoroacetic acid (SigmaAldrich, St. Louis, MO, USA), acetonitrile (Thermo Fisher Scientific, Oxford, UK), and ultrapure water produced using a Milli-Q system (Millipore, Burlington, MA, USA).

\subsection{Plant Material Collection and Extract Preparation.} Plant material used in this study consisted of stem bark samples (500 g) of wild P. africana provided by the Natural Chemotherapeutics Research Institute, Ministry of Health, Uganda. A voucher (specimen number KIOM201901022377) was deposited at the Korean Herbarium of Standard Herbal Resources (Index Herbarium code: KIOM) at the Korean Institute of Oriental Medicine (KIOM), Herbal Medicine Resources Research Center, South Korea.

The following sample types were used: wild $P$. africana stem bark (PWS) (Figure 1(a)), stem of a six-month-old micropropagated P. africana plant (PIS) (Figure 1(b)), roots of a six-month-old micropropagated $P$. africana plant (PIR) (Figure 1(c)), leaves of a six-month-old micropropagated $P$. africana plant (PIL) (Figure 1(d)), and $P$. africana calluses generated from leaf explants (PIC) (Figure 1(e)). Each sample was ground to a fine powder (Figure $1(\mathrm{~g})-1(\mathrm{j})$ ) and then extracted and concentrated as previously described [24]. Vacuum dried extracts were used for antiprostate cancer assays.

\subsection{High-Performance Liquid Chromatography (HPLC)} Analysis of P. africana. Powdered PWS, PIS, PIR, PIL, and PIC samples (500 mg, each) were sequentially extracted twice for $30 \mathrm{~min}$ using $50 \mathrm{~mL}$ methanol and an ultrasonicator. Each extract was concentrated in vacuo using an evaporator, followed by dissolving the extract in methanol at $50 \mu \mathrm{g} / \mathrm{mL}$ and 


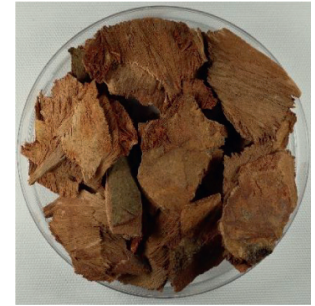

(a)

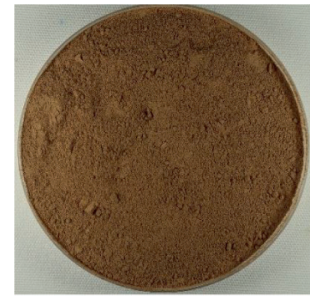

(f)

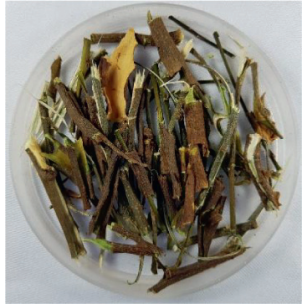

(b)

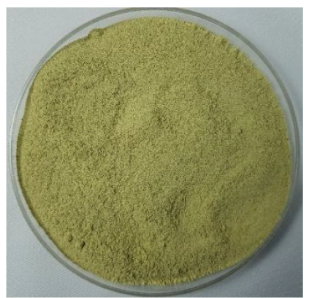

(g)

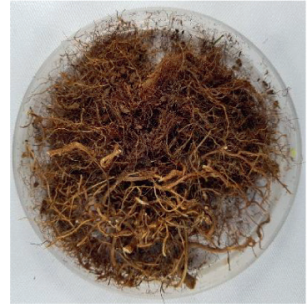

(c)

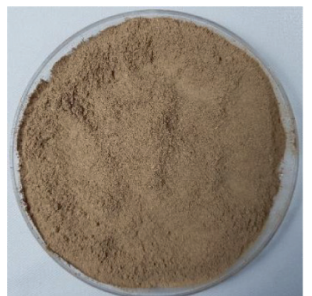

(h)

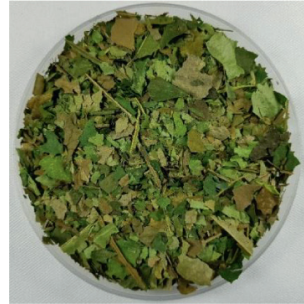

(d)

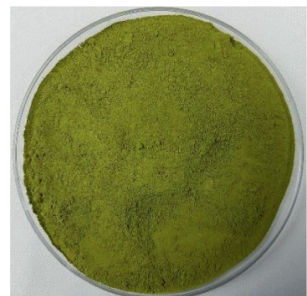

(i)

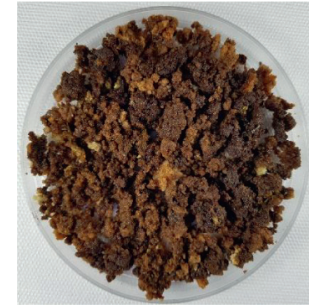

(e)

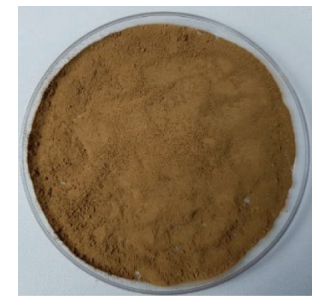

(j)

Figure 1: Prunus africana samples used in the experiment: (a) wild P. africana stem bark (PWS); (b) juvenile stem bark from cloned P. africana plant (PIS); (c) juvenile roots from cloned P. africana plant (PIR); (d) juvenile leaves from cloned P. africana plant (PIL); (e) in vitro callus from leaf explant (PC); (f) wild stem bark powder; (g) juvenile stem bark powder from cloned P. africana plant; (h) juvenile root powder from cloned P. africana plant; (i) juvenile leaves powder from cloned $P$. africana plant; (j) callus powder.

filtration through a $0.22 \mu \mathrm{m}$ membrane filter (Whatman International Ltd., Maidstone, UK). Samples were then stored at $4^{\circ} \mathrm{C}$ until use. HPLC was performed using a Dionex UltiMate 3000 system (DAD; Thermo Fisher Scientific, CA, USA). Output signals from the detector were processed using Chromeleon software (v. 7). A total of $10 \mu \mathrm{L}$ of each sample was injected using an autosampler. Chromatographic separation was achieved using a Gemini $\mathrm{C}_{18}$ column $(4.6 \times 250 \mathrm{~mm}, 5 \mu \mathrm{m}$; Phenomenex, Torrance, CA, USA) with the following mobile phases: $0.1 \%$ trifluoroacetic acid in water (v/v) as solvent $\mathrm{A}$ and acetonitrile as solvent $\mathrm{B}$ at a flow rate of $1 \mathrm{~mL} / \mathrm{min}$ with a total run time of $50 \mathrm{~min}$. HPLC elution conditions were optimized as follows: $0-2 \mathrm{~min}, 0 \%-3 \% \mathrm{~B}$; $2-30 \mathrm{~min}, 3 \%-35 \% \mathrm{~B} ; 30-31 \mathrm{~min}, 35 \%-50 \% \mathrm{~B} ; 31-35 \mathrm{~min}$, $50 \% \mathrm{~B} ; 35-40 \mathrm{~min}, 50 \%-100 \% \mathrm{~B} ; 40-45 \mathrm{~min}, 100 \% \mathrm{~B}$; 45-50 min, 3\% B; column oven temperature was $40^{\circ} \mathrm{C}$, and detection wavelengths were 203, 254, 280, and $320 \mathrm{~nm}$.

2.4. Gas Chromatography-Mass Spectrometry (GC-MS) Analysis of P. africana. Powdered PWS, PIS, PIR, PIL, and PIC samples (50 mg, each) were extracted using $1 \mathrm{~mL}$ $100 \%$ methanol and sonication for $30 \mathrm{~min}$, followed by filtration through a $0.2 \mu \mathrm{m}$ syringe membrane filter (Whatman International Ltd). Analysis was performed using a 7890B GC-MS system (Agilent Technologies, Atlanta, GA, USA) coupled with a 7977B model mass detector (Agilent Technologies) and using a DB-5 MS capillary column $(30 \mathrm{~m} \times 0.25 \mathrm{~mm} \times 0.25 \mu \mathrm{m})$. Briefly, $1 \mu \mathrm{L}$ extract was injected in split mode at a ratio of $1 / 20$ under the following chromatographic conditions: $250^{\circ} \mathrm{C}$ injection temperature and $50^{\circ} \mathrm{C}$ initial oven temperature, which was increased to $110^{\circ} \mathrm{C}$ over the next $5 \mathrm{~min}$ and then to $300^{\circ} \mathrm{C}$ at $7^{\circ} \mathrm{C} / \mathrm{min}$. A mass analyzer was used for scanning from 30 to $600 \mathrm{amu}$. Peaks were distinguished by comparison with experimental mass spectra at the $\mathrm{Na}$ tional Institute of Standards and Technology (NIST) and Wiley GC-MS libraries.

2.5. Fourier Transform Near-Infrared (FT-NIR) Analysis of P. africana. Powdered PWS, PIC, PIR, PIL, and PIS samples ( $3 \mathrm{~g}$, each) were placed in $22 \mathrm{~mm}$ vials and analyzed as previously described by Komakech et al. [23] using a TANGO FT-NIR spectrometer (Bruker Optics, Billerica, MA, USA).

2.6. Cancer Cell Line and Cell Culture Conditions. The PC-3 cell line was subcultured in tissue culture flasks containing Dulbecco's Modified Eagle Medium supplemented with 1\% penicillin-streptomycin, $10 \%$ fetal bovine serum, and $1 \%$ nonessential amino acids. Cells were incubated in a $\mathrm{CO}_{2}$ incubator at $5 \% \mathrm{CO}_{2}$ and $95 \%$ relative humidity. After trypsinization, cell counts were performed and cell viability was assessed using trypan blue staining and a hemocytometer. A known number of cells $\left(2 \times 10^{3}\right.$ cells/well in $100 \mu \mathrm{L}$ medium) were seeded in 96-well microtiter plates for the methyl tetrazolium bromide (MTT) assay.

2.7. Treatment and MTT Cell Viability Assay of PC-3 Cells. Antiprostate cancer effects of PWS, PIC, PIR, PIL, and PIS extracts were determined in vitro using an MTT assay with PC-3 cells. To enhance cell attachment, the PC-3 cells were seeded at a known density in 96-well microtiter plates and incubated at $37^{\circ} \mathrm{C}$ at $5 \% \mathrm{CO}_{2}$ and $95 \%$ relative humidity for $24 \mathrm{~h}$. After incubation, extracts were added to the cells at concentrations of $0,10,30,60,90$, or $270 \mu \mathrm{g} / \mathrm{mL}$. Doxorubicin was used as a positive control, and a blank control was included to which the same concentrations of fresh 
medium were added. The plates were incubated in a $\mathrm{CO}_{2}$ incubator for $48 \mathrm{~h}$ before aspirating the medium from each well. The cells were then washed using phosphate-buffered (PBS) solution before adding a fresh medium. A $30 \mu \mathrm{L}$ aliquot of MTT $(5 \mathrm{mg} / \mathrm{mL}$ in PBS) was added to each well, followed by incubation at $37^{\circ} \mathrm{C}$ for $4 \mathrm{~h}$. The medium was then aspirated, and dimethyl sulfoxide (DMSO) was added to solubilize any formazan crystals formed. After incubation with cell-counting kit solutions for $1 \mathrm{~h}$, absorbance was measured at $450 \mathrm{~nm}$ using a microplate reader (Versa Max), and cell growth inhibition caused by each extract was expressed as the corresponding $\mathrm{IC}_{50}$ value.

2.8. Apoptosis and Viability Assays. Apoptosis induced by PWS and PIR extracts was determined by staining PC-3 cells with fluorescein isothiocyanate annexin- $\mathrm{V}$ and propidium iodide (PI) stains using the FITC Annexin V Apoptosis Detection Kit II (BD Biosciences, San Jose, CA, USA), according to manufacturer instructions. Cells were stained for $20 \mathrm{~min}$ on ice using the appropriate antibodies in a binding buffer (PBS with 2\% FBS and $1 \mathrm{mM}$ EDTA); analysis was performed using a fluorescence-activated cell sorter (FACS Canto II; BD Biosciences). Cell viability was determined using Cell Counting Kit-8 (CCK-8; Dojindo Molecular Technologies, Rockville, MD, USA). Briefly, $2 \times 10^{4}$ cells $/ 100 \mu \mathrm{L}$ were seeded in a 96-well plate, treated with PWS and PIR extracts at concentrations of 10,30,60, 90, and $270 \mu \mathrm{g} / \mathrm{ml}$ and incubated at $37^{\circ} \mathrm{C}$ for $48 \mathrm{~h}$. Then, $10 \mu \mathrm{L}$ CCK- 8 was added to each well, and absorbance was measured at $450 \mathrm{~nm}$ using the SpectraMax i3x Multi-Mode Microplate Reader (Molecular Devices, San Jose, CA, USA).

2.9. Western Blot Analysis of PC-3 Cells after Treatment with P. africana Extracts. Proteins were extracted from PC-3 cells treated with different concentrations $(0,10,30,60,90$, and $270 \mu \mathrm{g} / \mathrm{mL})$ of PWS and PIR extracts using RIPA buffer $(50 \mathrm{mM}$ Tris-HCl, $\mathrm{pH} 7.4,150 \mathrm{mM} \mathrm{NaCl}, 1 \%$ Triton X-100, 0.5\% sodium deoxycholate, $0.1 \%$ SDS) (GenDEPOT, Baker, TX, USA). The cell lysate was separated on $8 \%-15 \%$ SDS-PAGE gels and transferred to PVDF membranes (Millipore, Bedford, MA, USA) treated with primary antibodies against cleaved caspase-3 (9661; Cell Signaling Technology, Danvers, MA, USA) and actin (sc-47778; Santa Cruz Biotechnology, Dallas TX, USA). After incubation with peroxidase-conjugated anti-rabbit or antimouse IgG (Jackson ImmunoResearch, West Gove, PA, USA), signals were detected using SuperSignal West Pico Chemiluminescent Substrate (Pierce). Western blots were visualized using WSE-6100 LuminoGraph (ATTO, Tokyo, Japan).

2.10. 4',6-Diamidino-2-Phenylindole (DAPI) Staining. PC-3 cells were maintained in Roswell Park Memorial Institute (RPMI) 1640 medium supplemented with $10 \%(\mathrm{v} / \mathrm{v})$ fetal bovine serum and antibiotics. Cells were seeded on an eight-well slide and incubated overnight. After $24 \mathrm{~h}$, cells were treated with respective $\mathrm{IC}_{50}$ concentrations of PWS $(52.30 \mu \mathrm{g} / \mathrm{ml})$ and PIR $(82.40 \mu \mathrm{g} / \mathrm{ml})$, negative control cells were treated with DMSO (0.1\%), and positive control cells treated with doxorubicin $(1.13 \mathrm{uM})$ and incubated for $48 \mathrm{~h}$. Incubated cells were washed with PBS, fixed with $2 \%$ paraformaldehyde and stained with DAPI $(1 \mu \mathrm{g} / \mathrm{mL})$, and incubated for $5 \mathrm{~min}$. Cells placed on slides were observed under a fluorescence microscope (Olympus CKX53; Olympus, Tokyo, Japan). The criteria defining apoptosis of DAPI staining, such as nuclear pyknosis and fragmentation, were applied as described in a previous study [25]. The number of nuclei showing these morphological characteristics was counted as DAPI positive cells under the immunofluorescence microscope at $40 \times$ magnification. For each sample, three independent areas of interest with at least 1000 total nuclei per area were counted using Image J software and DAPI positive cells were showed as \% of total cells. Statistical analyses were performed using a one-way analysis of variance (ANOVA) with GraphPad Prism 8.4.3.

2.11. Statistical Analysis. Means, standard error of the means, and proportions were determined. $\mathrm{LC}_{50}$ values were determined using linear regression. The data were analyzed by ANOVA, and differences were tested using Bonferroni's post hoc test implemented in GraphPad Prism software (ver. 5. 03). Statistical significance is reported at $p<0.05$. FT-NIR spectroscopy multivariate statistical analyses were performed, and Ward's algorithm was calculated using OPUS TANGO-R software for homogeneity cluster analysis.

\section{Results}

3.1. High-Performance Liquid Chromatography Analysis of $P$. africana. Finger-printing analysis results of $P$. africana extract are shown in Figure 2. Sufficient selectivity and separation were recorded at 254 and $320 \mathrm{~nm}$, respectively. Relative to PWS, sample PIS showed comparable component patterns at 15-20 min (Part I) and 40-45 min (Part II), although peak intensities differed. The components of sample PIC were comparable to those of sample PIR; in particular, these profiles appeared to be quite similar in Part I and Part II of the chromatogram at $320 \mathrm{~nm}$. Among the five different $P$. africana sample types, sample PIL showed the most complex pattern, with various component profiles at all applied UV wavelengths.

3.2. Gas Chromatography-Mass Spectrometry Analysis of $P$. africana. Based on mass spectra, retention times, and quality ratio analysis, GC-MS analysis results for PWS extract indicated 32 components (Figure 3 and Table 1). Identified compounds included benzoic acid (14.02\%), $\beta$-sitosterol $(8.37 \%), 13$-docoseamide $(6.49 \%)$, and $n$-hexadecanoic acid (4.95\%). Comparative analyses of the other extracts were performed based on the chemical composition of PWS extract. According to mass spectra and retention times (Table 1), 4H-pyran-4-one,2,3-dihydro-3,5-dihydroxy-6-methyl- (4), benzoic acid (5), 5-hydroxymethyl-2-furaldehyde (8), n-hexadecanoic acid (23), 9,12-octadecadienoic acid (Z, Z)(24), octadecanoic acid (26), 9-octadecenamide, (Z)- (28), 13docosenamide, (Z)- (30), and $\beta$-sitosterol (32) were present in all extracts. Among these nine components, (5) represented 

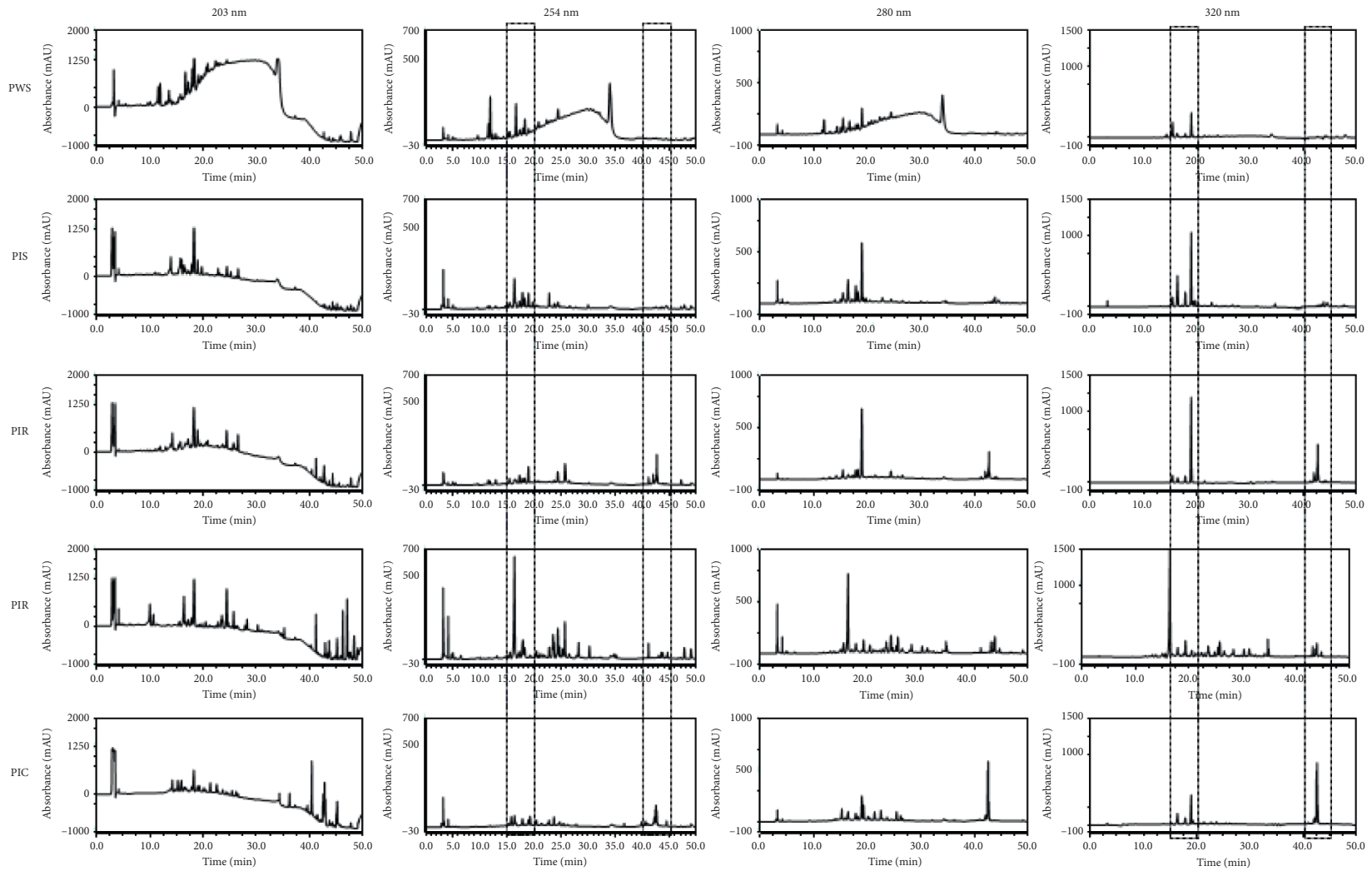

FIGURE 2: Finger-printing analysis of the extracts derived from $P$. africana by the HPLC-DAD method. PWS, mature $P$. africana stem bark; PIS, stem bark of juvenile cloned P. africana; PIR, root of juvenile cloned P. africana; PIL, leaves of juvenile cloned $P$. africana; PIC, callus generated from leaf explant of $P$. africana. Part I: retention part, 15-20 min; Part II: retention part, 40-45 min.

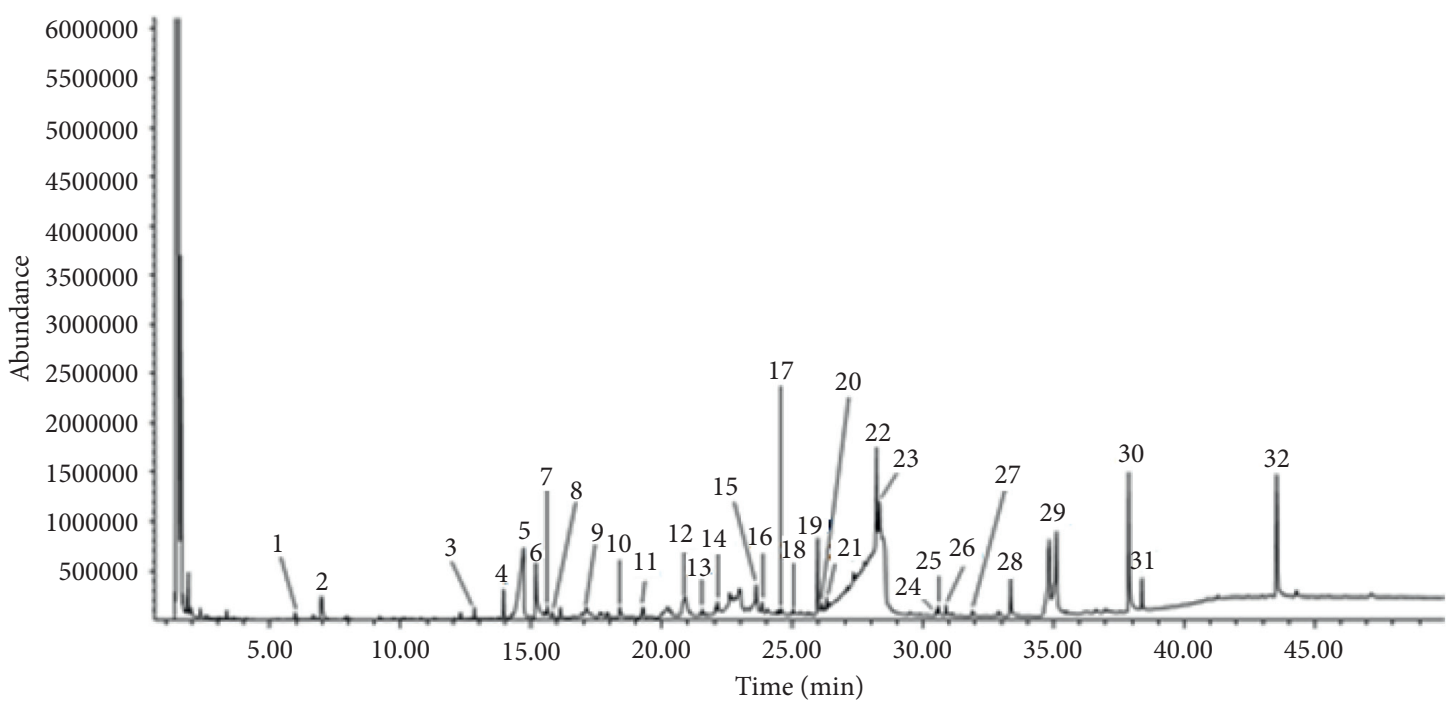

Figure 3: GC/MS chromatogram of the methanol extract of sample PWS.

the largest proportion of all compounds detected in a callus extract, compared with the PWS extract. In contrast, five components, including 3,4-altrosan (12), benzenepropanol, 4-hydroxy-3-methoxy- (15), benzaldehyde, 4-hydroxy-3, 5dimethoxy- (16), 4-(hydroxymethyl)-2,6-dimethoxyphenol (17), and 6-hydroxy-5-trifluoromethylcyclohexa-1,3-diene (19), occurred only in PWS extracts. Vanillic acid (14) and
(R)-alpha-( $\beta$-D-glucopyranosyloxy) benzene-acetonitrile (29) were detected in PWS and PIS extracts.

3.3. Fourier Transform Near-Infrared Analysis of P. africana. FT-NIR analyses of PWS, PIC, PIR, PIL, and PIS samples showed six prominent FT-NIR peaks within the region 
TABle 1: Phytochemical components detected in the methanol extract of $P$. africana experimental materials by GC/MS analysis. $t_{R}$ : retention time (min); \%: percent of total.

\begin{tabular}{|c|c|c|c|c|c|c|c|c|c|c|c|}
\hline \multirow{2}{*}{ No. } & \multirow{2}{*}{ Identified compound } & \multicolumn{2}{|c|}{ PWS } & \multicolumn{2}{|c|}{ PIS } & \multicolumn{2}{|c|}{ PIR } & \multicolumn{2}{|c|}{ PIL } & \multicolumn{2}{|c|}{ PC } \\
\hline & & $t_{R}^{1}$ & $\% 2$ & $t R$ & $\%$ & $t R$ & $\%$ & $t R$ & $\%$ & $t R$ & $\%$ \\
\hline 1 & 3-Furanmethanol & 5.96 & 0.39 & - & - & - & - & 5.97 & 0.16 & 5.97 & 0.79 \\
\hline 2 & Dihydroxyacetone & 7.01 & 2.22 & 6.96 & 0.72 & - & - & 7.01 & 0.62 & 7.10 & 1.31 \\
\hline 3 & Benzoic acid, methyl ester & 12.83 & 0.46 & - & - & - & - & 8.11 & 0.35 & - & - \\
\hline 4 & 4H-Pyran-4-one,2,3-dihydro-3,5-dihydroxy-6-methyl- & 13.95 & 1.13 & 13.95 & 0.63 & 13.94 & 0.66 & 9.19 & 0.06 & 14.00 & 2.87 \\
\hline 5 & Benzoic acid & 14.68 & 14.02 & 14.60 & 3.10 & 14.55 & 1.83 & 12.83 & 0.15 & 14.48 & 0.71 \\
\hline 6 & Catechol & 15.17 & 4.74 & - & - & 15.17 & 0.32 & 13.97 & 0.80 & - & - \\
\hline 7 & 4-Vinylphenol & 15.61 & 0.77 & 15.62 & 0.65 & 15.63 & 0.80 & 14.99 & 6.79 & - & - \\
\hline 8 & 5-Hydroxymethyl-2-furaldhyde & 15.81 & 0.31 & 15.81 & 0.81 & 15.81 & 0.11 & 15.20 & 0.80 & 16.03 & 24.79 \\
\hline 9 & Isosorbide & 17.10 & 0.98 & - & - & - & - & 15.62 & 1.66 & - & - \\
\hline 10 & Phenol, 2,6-dimethoxy- & 18.39 & 0.41 & - & - & 18.39 & 0.04 & 15.83 & 0.32 & - & - \\
\hline 11 & 4-Hydroxy-3-methoxybenzaldehyde & 19.30 & 0.41 & 25.03 & 0.14 & - & - & - & - & - & - \\
\hline 12 & 3,4-Altros & 20.84 & 3.30 & - & - & - & - & - & - & - & - \\
\hline 13 & Mandelamide & 21.54 & 0.40 & - & - & - & - & 21.64 & 1.41 & - & - \\
\hline 14 & Vanillic acid & 22.13 & 0.93 & - & - & 22.12 & 0.78 & - & - & - & - \\
\hline 15 & Benzenepropanol, & 23.61 & 2.14 & - & - & - & - & - & - & - & - \\
\hline 16 & Benzaldeh & 23.83 & 0.75 & - & - & - & - & - & - & - & - \\
\hline 17 & 4-(Hydroxymethyl)-2,6 & 24.57 & 0.17 & - & - & - & - & - & - & - & - \\
\hline 18 & (E)-4-(3-Hydroxyprop-1-en-1-yl)-2-methoxyphenol & 25.03 & 0.18 & 25.03 & 0.14 & 25.03 & 0.10 & 25.05 & 0.38 & - & - \\
\hline 19 & 6-Hydroxy-5-trifluoromethylcyclohexa-1,3-diene & 25.98 & 3.65 & - & - & - & - & - & - & - & - \\
\hline 20 & Benzoic acid, 4-hydroxy-3,5-dimethoxy- & 26.13 & 0.29 & 26.12 & 0.08 & 26.20 & 0.13 & - & - & - & - \\
\hline 21 & Isopropyl myristate & 26.31 & 0.40 & 26.31 & 0.15 & - & - & - & - & - & - \\
\hline 22 & Sorbitol & 27.95 & 0.05 & 27.00 & 0.09 & 29.62 & 5.75 & 29.82 & 2.88 & - & - \\
\hline 23 & n-Hexadecanc & 28.21 & 4.95 & 28.22 & 2.34 & 28.22 & 3.72 & 28.24 & 1.52 & 28.23 & 3.18 \\
\hline 24 & 9,12-Octadecadienoic acid (Z, Z)- & 30.51 & 0.20 & 30.52 & 0.79 & 30.52 & 0.64 & 30.57 & 0.88 & 30.52 & 0.21 \\
\hline 25 & Oleic acid & 30.58 & 0.76 & 30.60 & 0.99 & - & - & - & - & 30.60 & 1.72 \\
\hline 26 & Octadecanoic acid & 30.87 & 0.47 & 30.87 & 0.66 & - & - & 30.89 & 0.58 & 30.88 & 0.69 \\
\hline 27 & Benzyl, beta-d-glucoside & 31.90 & 0.32 & 31.90 & 0.17 & - & - & 32.05 & 0.28 & 31.97 & 0.16 \\
\hline 28 & 9-Octadecenamide, (Z)- & 33.35 & 1.95 & 33.35 & 0.80 & 33.35 & 1.05 & 33.36 & 0.33 & 33.35 & 0.59 \\
\hline 29 & (R)-alpha-(beta-D-glucopyranosyloxy)benzene-acetonitrile & 35.10 & 6.60 & - & - & 35.10 & 1.91 & - & - & - & - \\
\hline 30 & 13-Docosenamide, $(Z)$ - & 37.88 & 6.49 & 37.88 & 6.76 & 37.88 & 4.53 & 37.88 & 0.93 & 37.87 & 1.07 \\
\hline 31 & Squalene & 38.38 & 1.09 & - & - & - & - & 38.40 & 5.34 & - & - \\
\hline 32 & Beta-sitosterol & 43.55 & 8.37 & 43.57 & 16.77 & 43.56 & 7.75 & 43.56 & 4.76 & 43.55 & 4.02 \\
\hline
\end{tabular}

between 8,500 and $4,000 \mathrm{~cm}^{-1}$, which included peaks at 8,273 , $6,867,6,344,5,875-5,688,5,172$, and $4,938-4,500 \mathrm{~cm}^{-1}$ (Figure 4(a)). The vertical scale of the dendrogram (Figure 4(b)) indicates the numerical distance between PWS, PIC, PIR, PIL, and PIS; as can be seen, all samples showed high heterogeneity at a distance of approximately 0.45 . However, PIS, PIL, and PWS showed higher similarity and clustered with a spectral distance (heterogeneity) of 0.18 , and further separation was observed in which PIL and PWS showed a closest spectral distance (heterogeneity) of approximately 0.12 . Similarly, PIC and PIR clustered with a spectral distance (heterogeneity) of approximately 0.24 .

\subsection{In Vitro Anticancer Effects of P. africana Extracts on PC-3} Cancer Cells. A preliminary test failed to show any remarkable concentration-dependent antiprostate cancer effects from PIS, PIL, or PIC on PC-3 cell lines, whereby they were excluded from the main experiment. In contrast, PWS and PIR did show dose-dependent antiprostate cancer effects on PC-3 cells after exposure for $48 \mathrm{~h}$. Therefore, we determined cancer cell viability using the CCK- 8 assay and obtained $\mathrm{IC}_{50}$ values of 52.30 and $82.40 \mu \mathrm{g} / \mathrm{mL}$ for PWS and PIR, respectively (Figure 5).
3.5. Annexin-V and PI Staining. To confirm that PWS and PIR induced apoptosis in PC-3 cells, we examined apoptosis levels after incubation with PWS and PIR extracts for $48 \mathrm{~h}$ using FACS, followed by annexin-V and PI staining. PWS and PIR induced apoptosis in PC-3 cells in a dose-dependent manner. Specifically, treatment with PWS produced a higher proportion of apoptotic cells than the PIR treatment (Figure 6(a)). The proportion of apoptotic cells correlated positively with extract concentration; furthermore, PWS at $90 \mu \mathrm{g} / \mathrm{mL}$ resulted in $37.3 \%$ apoptotic cells, compared with 13.3\% caused by PIR treatment (Figure 6(b)). A similar trend was observed for trypan blue staining, which showed more dead cells under the PWS treatment than under the PIR treatment (Figure 6(c)).

3.6. 4',6-Diamidino-2-Phenylindole (DAPI) Staining. The proportion of DAPI-stained apoptotic PC-3 cells following treatment with DMSO, PWS, PIR, and doxorubicin was $10.5 \%$, $27 \%, 28 \%$, and $27.5 \%$, respectively (Figure 7 ). Furthermore, DAPI (4',6-diamidino-2-phenylindole) staining showed significant $(p<0.001)$ induction of cell death after treatment with PWS, PIR, or doxorubicin (positive control), compared with 


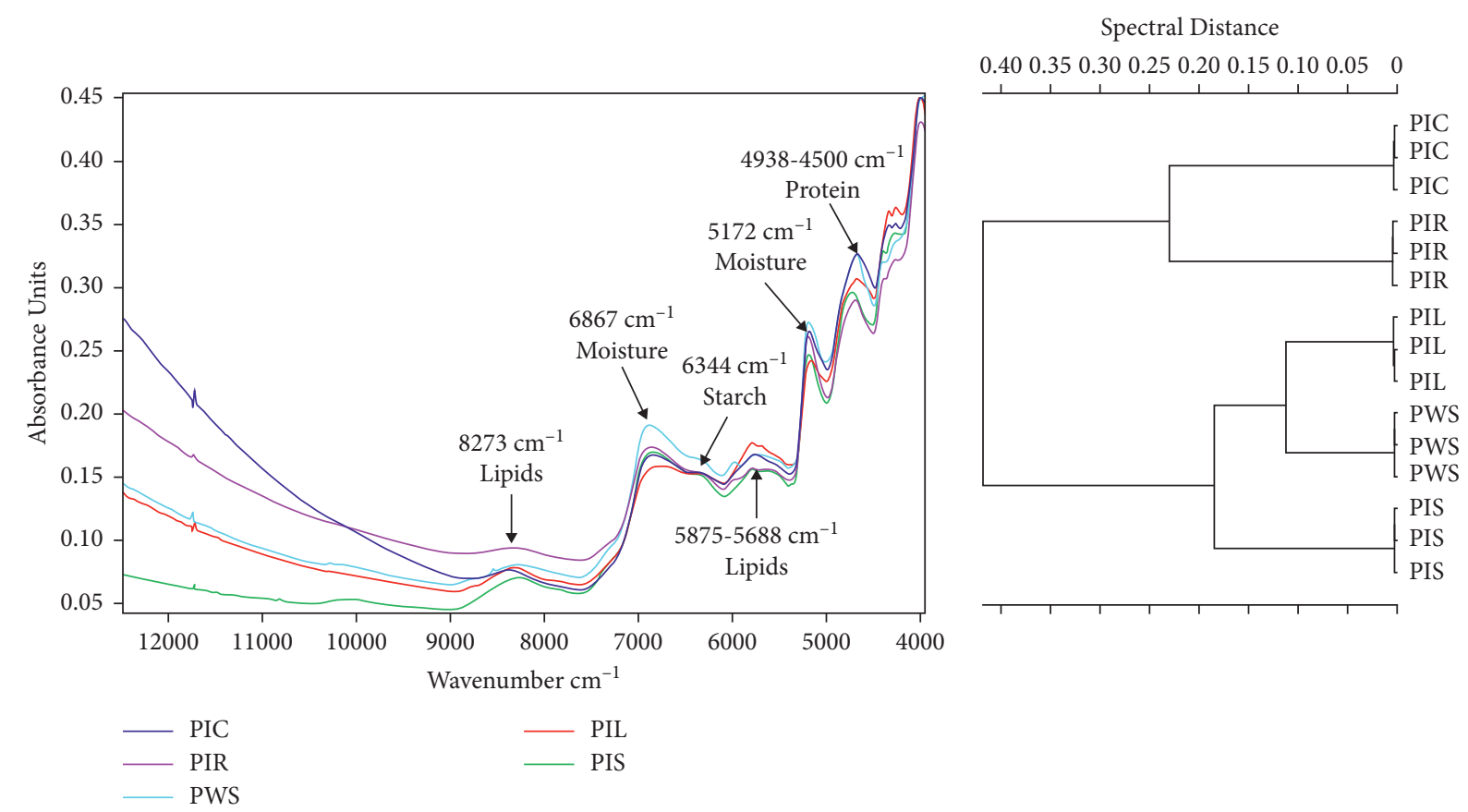

FIgURE 4: Multivariate statistical analysis of different samples obtained from in vitro regenerated and wild Prunus africana plants. (a) TANGO FT-NIR spectroscopy analysis results (wave number frequency range $=12,000-4,000 \mathrm{~cm}^{-1}$ ). (b). FT-NIR chemical characterization based on Ward's algorithm clustering dendrogram (data preprocessing-first derivative + vector normalization; standard (Euclidean distance); frequency range $=12,000-4,000 \mathrm{~cm}^{-1}$ ). PIC, P. africana callus sample; PIR, root sample obtained from in vitro regenerated P. africana plant; PIL, leaf sample obtained from in vitro regenerated $P$. africana plant; PWS, stem sample obtained from mature wild $P$. africana plant; PIS, stem sample obtained from in vitro regenerated $P$. africana plant.

the negative control, with no significant difference observed among PWS, PIR, or doxorubicin-treated cells.

3.7. Western Blot Analysis. Caspase-3 activation was determined by western blotting of cleaved caspase-3. PWS treatment induced higher cleaved caspase-3 levels in PC-3 cells than PIR treatment, an indication that PWS induced substantial apoptosis in PC-3 cells compared with PIR (Figure 8).

\section{Discussion}

FT-NIR spectrometry has been used in numerous studies to characterize chemicals present in samples [23, 26]. The absorption band at $8,273 \mathrm{~cm}^{-1}$ in the current study was due to the second $\mathrm{C}-\mathrm{H}$ overtone produced by lipids; in turn, the peak at $6,867 \mathrm{~cm}^{-1}$ was due to the first $\mathrm{O}-\mathrm{H}$ overtone caused by moisture, while the peak at $6,344 \mathrm{~cm}^{-1}$ was due to the first $\mathrm{O}-\mathrm{H}$ overtone linked to starches; additionally, the peak at $5,875-5,688 \mathrm{~cm}^{-1}$ was due to the first $\mathrm{C}-\mathrm{H}$ overtone linked to lipids; in turn absorbance peaks between 4,938 and $4,500 \mathrm{~cm}^{-1}$ resulted from the combination of $\mathrm{N}-\mathrm{H}, \mathrm{O}-\mathrm{H}$, and $\mathrm{C}-\mathrm{H}$ stretching associated with proteins [26-29]. Therefore, the similarity in the peaks of these samples associated with specific functional groups offers an indication of the high degree of chemical homogeneity among PWS, PIS, PIR, PIL, and PIC samples. Ward's algorithm clustering has been commonly used to characterize samples [30]. The dendrogram constructed herein showed high heterogeneity among PWS, PIS, PIR, PIL, and PIC samples, presumably due to higher similarity of the various near-infrared spectra generated by the respective sample. As shorter distances between samples indicate close chemical phylogenetic relationships, the similarity of these samples regarding antiprostate cancer effects may be due to the similarity in chemical composition among different $P$. africana samples.

In recent years, plant-derived phytochemicals have been widely used as chemopreventive and chemotherapeutic agents for treating various cancers, including prostate cancer [31]. In this study, numerous phytochemicals present in $P$. africana extracts were identified (Table 1), and antiprostate cancer effects of the $P$. africana samples examined may be associated with some of these compounds. $\beta$-Sitosterol is one of the phytochemicals contributing to the antiprostate cancer effects of $P$. africana [18] and has been observed to induce apoptosis in human prostate cancer cells in cases of prostate lymph-node carcinoma [32, 33].

Nuclear factor kappa-B (NF- $\kappa \mathrm{B})$ inhibition is crucial in the arrest of cancer cell growth [34], and it exerts antimutagenic effects [35]. Therefore, the presence of 2,3-dihydro-3,5-dihydroxy-6-methyl-4H-pyran-one in $P$. africana extracts may be responsible for the antiproliferative and proapoptotic effects of the different extracts on PC-3 cancer cells due to its ability to inactivate NF- $\kappa \mathrm{B}$. Additionally, the presence of benzoic acid in $P$. africana extracts may also be responsible for its anticancer effects. Indeed, previous studies revealed that benzoic acid derivatives delayed prostate cancercell growth, thereby preventing the expression of oncogenes by inhibiting histone deacetylases [36]. 

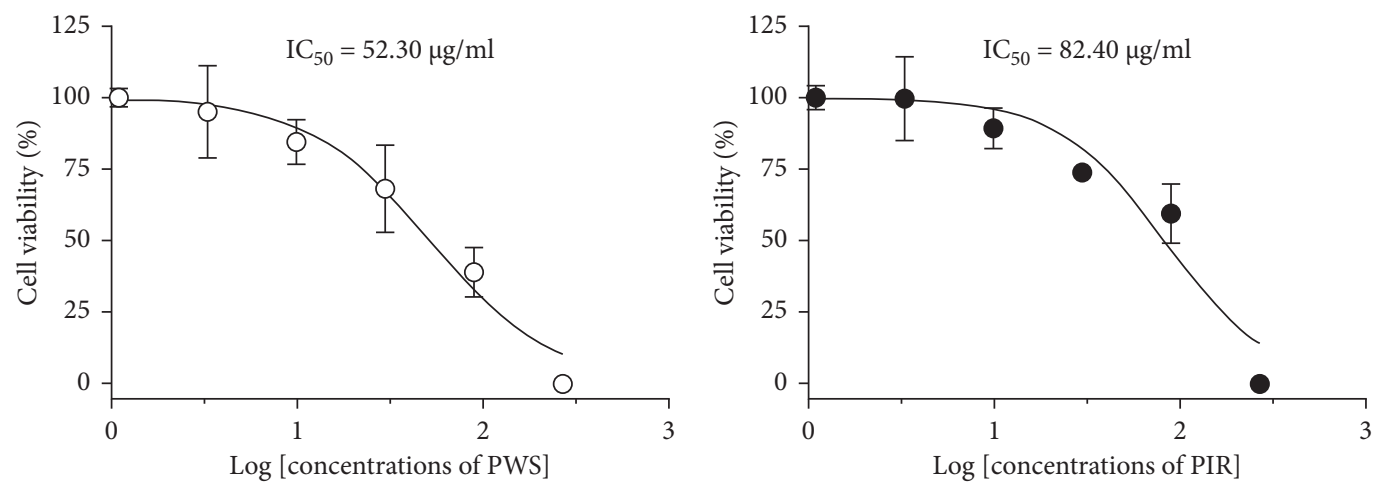

FIGURE 5: CCK-8 assay of PC-3 cells viability when exposed for $48 \mathrm{~h}$ at different concentrations of PWS and PIR samples. Results were expressed as percentage of cell viability and each point expressed as mean $\pm \mathrm{SD}(N=3) . \mathrm{IC}_{50}$ values are calculated by using GraphPad Prism software.

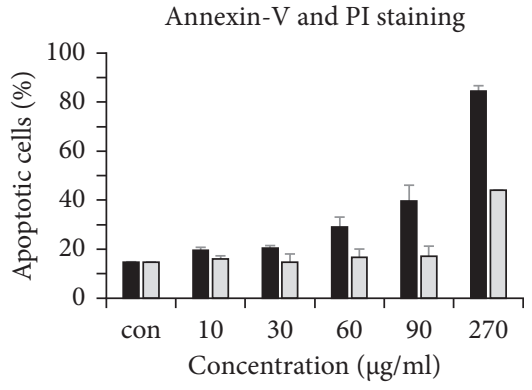

PWS

$\square$ PIR

(a)

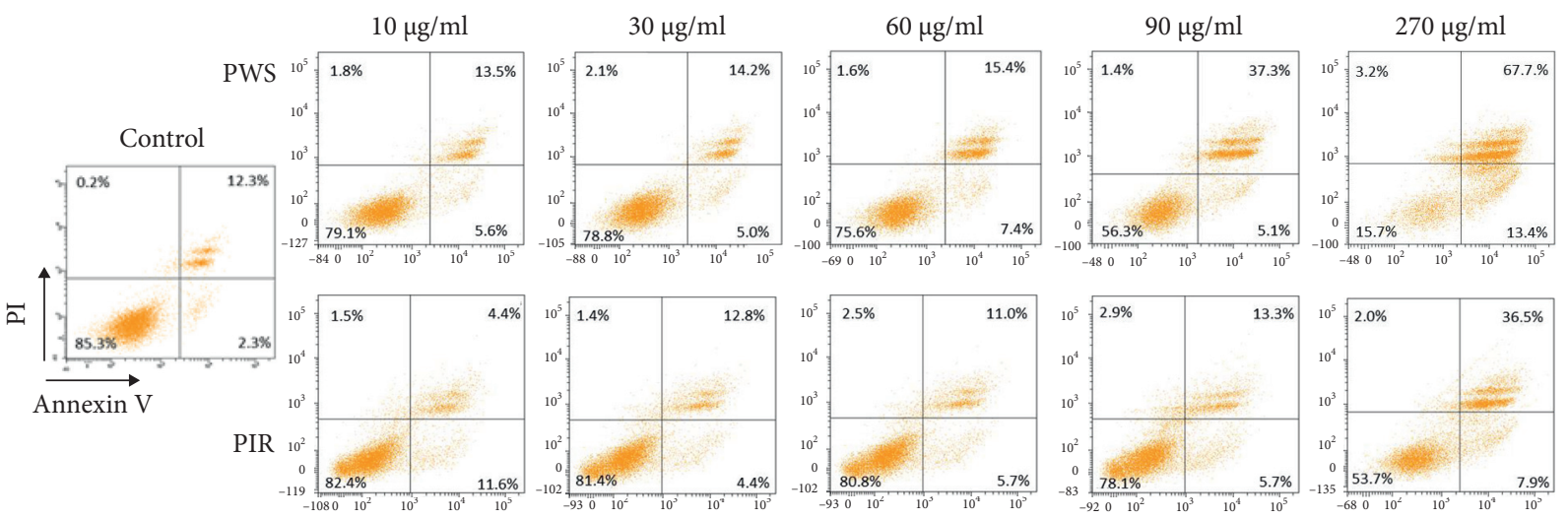

(b)

Figure 6: Continued. 


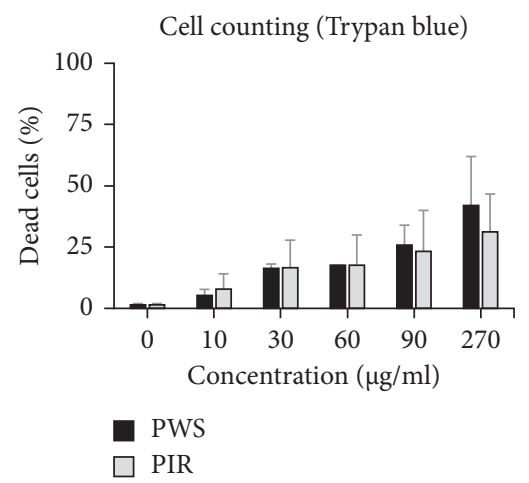

(c)

FIgURE 6: Apoptosis assay of PC-3 cells after $48 \mathrm{~h}$ treatment with PWS and PIR samples. (a) Apoptosis levels after annexin-V and PI staining of treated PC3-cells. (b) Apoptosis levels of treated PC-3 cells by flow cytometry (FACS) after annexin-V and PI staining (the upper left quadrant indicates necrotic cells (annexin $\mathrm{V}(-) / \mathrm{PI}(+)$ ), the upper right quadrant indicates late apoptotic cells $($ annexin $\mathrm{V}(+) / \mathrm{PI}(+)$ ), lower right quadrant indicates early apoptotic cells (annexin $\mathrm{V}(+) / \mathrm{PI}(-)$ ), and the lower left quadrant indicates healthy cells (annexin $\mathrm{V}(-) / \mathrm{PI}$ $(-))$. (c) Dead cells of treated PC-3 cells when stained with trypan blue.
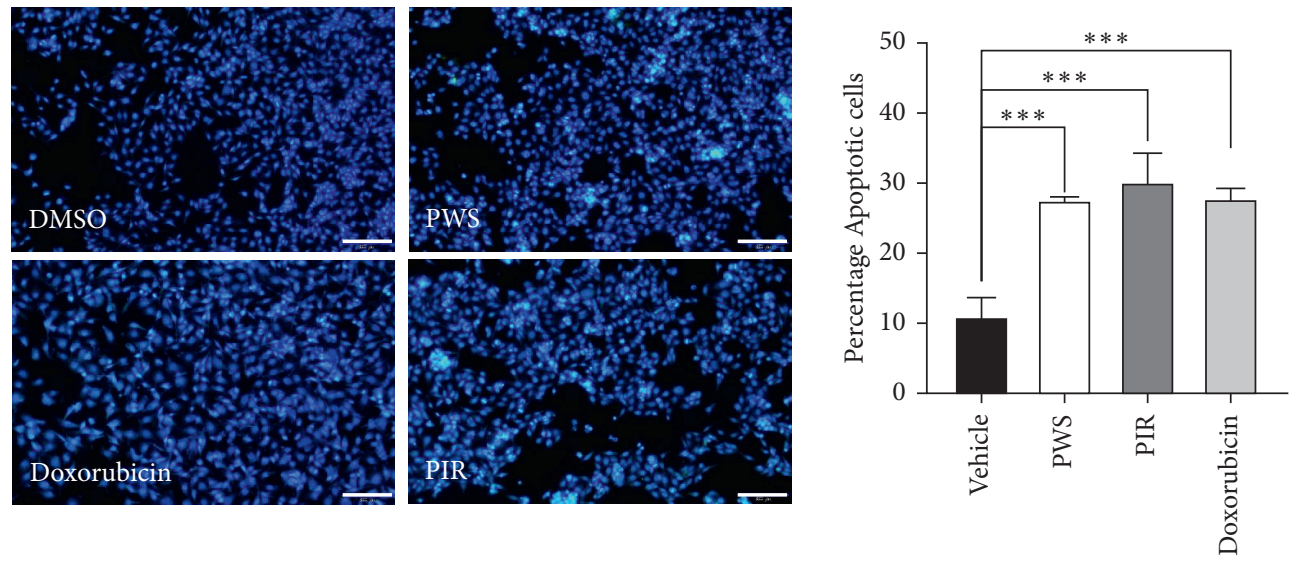

FIgURE 7: Changes in PC-3 cells nuclear condensation observed after DAPI staining when treated with PWS ( $52.30 \mu \mathrm{g} / \mathrm{ml})$ or PIR (82.40 $\mu \mathrm{g} / \mathrm{ml})$, vehicle $(0.1 \% \mathrm{DMSO})$, and doxorubicin $(1.13 \mathrm{uM})$ as a positive control and incubated for $48 \mathrm{~h}$. Representative image and percentage of apoptotic cells were shown. ${ }^{* * *} p<0.001$ compared with vehicle-treated controls.

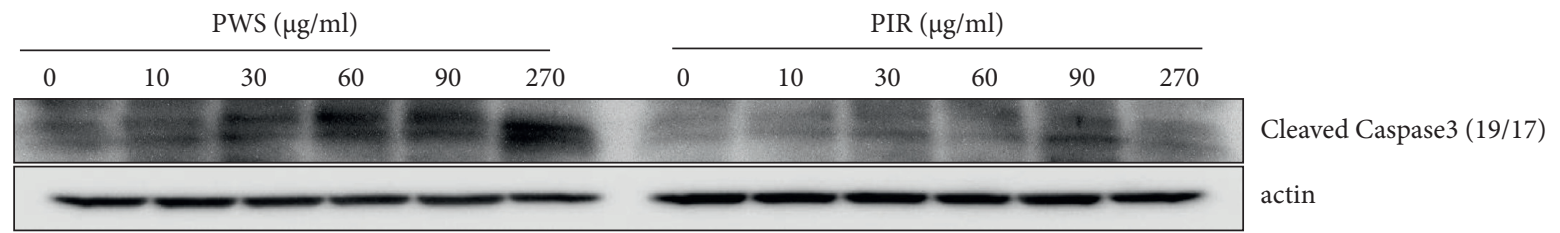

FIGURe 8: Western blot analysis of PC-3 after $48 \mathrm{~h}$ treatment with PWS and PIR samples.

Annexin-V and PI staining are important techniques for accurate assessment of cell death [37]. Hence, to determine whether the growth inhibitory effect of PWS and PIR on PC3 cells was associated with the induction of apoptosis, the cells were stained with Annexin V-FITC and propidium iodide. Annexin $\mathrm{V}$ is a calcium-dependent phospholipid-binding protein with a high binding affinity for phosphatidylserinephospholipid, which is exposed at the outer layer of the cell membrane during the initial stages of apoptosis [38, 39]. Conjugation of a fluorophore to Annexin V (FITC) therefore allows for detection of early apoptotic cells. Also, as apoptosis progresses, the cell membrane loses integrity and cells become necrotic. At this stage, propidium iodide-a fluorescent viability dye, which is impermeable to the cell membrane-diffuses freely into dying cells. Therefore, staining of cells with annexin V in conjunction with PI is usually done to establish the integrity of the cell membrane and distinguish living cells from both early and late apoptosis [40]. In the present study, annexin-V and PI staining showed significant induction of PC-3 cell death after 
treatment with PWS and PIR extracts. As depicted in Figure 6, exposure of cells to PWS and PIR increased the proportion of apoptotic cells (both early and late apoptosis) in comparison with negative control cells, although PWS displayed higher apoptosis-inducing capacity compared with PIR. The extracts displayed different chemical profiles. Some of the major compounds identified in PWS were either absent or only found as minor constituents in PIR. This may partly account for the increased apoptosis-inducing effects of PWS since some of these bioactive compounds (e.g., squalene and vanillic acid) are known to induce apoptosis in cancer cells.

DAPI is a DNA-specific fluorochrome that binds strongly to adenine-thymine-rich regions of DNA and is widely used to analyze nuclear morphologic changes such as DNA fragmentation during apoptosis [41]. In the present study, the nuclear features of the cells were examined by DAPI staining. DAPI is known to only inefficiently pass through an intact cell membrane and hence preferentially stain dead cells [42] including dead PC-3 cells [43]. As depicted in Figure 7, data from this study showed that nuclei of the negative control cells were homogeneously stained with DAPI and displayed less blue fluorescence intensity due to the presence of more intact cell membrane compared with the higher staining intensity of the cells treated with PWS, PIR, and doxorubicin, which suggest a compromised apoptotic cell membrane. PC-3 cells treated with PWS, PIR, and doxorubicin (positive control) showed altered nuclear DNA staining, nuclear fragmentation, and condensation. In fact, the DAPI staining is an indication of PC-3 cell death via apoptosis [44].

In a previous in vitro anticancer activity study, P. africana stem bark methanolic and aqueous extracts had respective $\mathrm{IC}_{50}$ values of $24.4 \pm 3.6$ and $19.9 \pm 0.9 \mu \mathrm{g} / \mathrm{ml}$ against DU-145 prostate cancer cell lines [45]. In the same study, when these same extracts were tested against 22RV1 prostate cancer cell lines, the $\mathrm{IC}_{50}$ values were $19.6 \pm 5.8$ and $20.7 \pm 0.8 \mu \mathrm{g} / \mathrm{ml}$ for methanolic and aqueous extracts, respectively [45]. Compared with our findings, the $\mathrm{IC}_{50}$ values greatly differed. The differences in the $\mathrm{IC}_{50}$ values could be attributed to differences in the prostate cancer cell lines and extractants used. A study by Ghagane et al. [46] demonstrated that indeed the type of extracting solvent significantly influenced growth inhibition levels of PC-3 and DU-145 prostate cancer cell lines and thus the $\mathrm{IC}_{50}$ values. Another study by Yesil-Celiktas et al. [47] showed that different cancer cell lines were inhibited to varying degree by plant extracts.

Caspases are responsible for cell apoptosis, and specifically, caspase- 3 activation plays a critical role in the execution of all apoptosis signaling pathways [48, 49]. Therefore, the detection of elevated levels of cleaved caspase- 3 by western blotting following PWS and PIR treatment is a strong indication of apoptotic cell death in PC-3 cells via the intrinsic apoptosis pathway. In a previous in vitro study, the stem bark extract of $P$. africana was also observed to exhibit significant apoptosis in the PC-3 cell line and lymph node carcinoma of the prostate (LNCaP) [18].

\section{Conclusion}

PIR extracts exhibited a dose-dependent, in vitro antiprostate cancer effect on PC-3 prostate cancer cells similar to that of the traditional PWS extract. Therefore, these extracts can be used as an alternative to stem bark collected from wild populations of $P$. africana, which may contribute to mitigating the threat of overexploitation of this endangered species. Furthermore, this study provides a sound theoretical basis for further research on the development of new prostate-cancer drugs from micropropagated $P$. africana plants.

\section{Data Availability}

The data for this current study are available from the corresponding author upon reasonable request.

\section{Disclosure}

Richard Komakech and Nam-Hui Yim are first coauthors.

\section{Conflicts of Interest}

The authors declare that there are no conflicts of interest regarding the publication of this review paper.

\section{Authors' Contributions}

Richard Komakech and Nam-Hui Yim contributed equally to this work as first coauthors.

\section{Acknowledgments}

This study was supported under the framework of International Cooperation Program (Korea-South Africa Cooperative Research Project for Excavation of Candidate Resources of Complementary and Alternative Medicine) managed by the National Research Foundation of Korea (grant nos. 2017093655 and KIOM: D17470). Additionally, this work was also supported by the Development of Foundational Techniques for the Domestic Production of Herbal Medicines (K18405), Development of Sustainable Application for Standard Herbal Resources (KSN2012320), and Korea Institute of Oriental Medicine through the Ministry of Science and ICT, Republic of Korea. This study was also supported by the University of Science and Technology (UST) overseas training grant (UST 2019-2020) for part of the research conducted at the University of the Free State, Republic of South Africa.

\section{References}

[1] D. O. Ochwang'i, C. N. Kimwele, J. A. Oduma, P. K. Gathumbi, J. M. Mbaria, and S. G. Kiama, "Medicinal plants used in treatment and management of cancer in Kakamega County, Kenya," Journal of Ethnopharmacology, vol. 151, no. 3, pp. 1040-1055, 2014.

[2] P. Rawla, "Epidemiology of prostate cancer," World Journal of Oncology, vol. 10, no. 2, pp. 63-89, 2019. 
[3] V. Steenkamp, "Phytomedicines for the prostate," Fitoterapia, vol. 74, no. 6, pp. 545-552, 2003.

[4] N. J. Toyang, H. K. Wabo, E. N. Ateh et al., "In vitro antiprostate cancer and ex vivo antiangiogenic activity of vernonia guineensis benth (asteraceae) tuber extracts," Journal of Ethnopharmacology, vol. 141, no. 3, pp. 866-871, 2012.

[5] H. Ting, G. Deep, C. Agarwal, and R. Agarwal, "The strategies to control prostate cancer by chemoprevention approaches," Mutation Research/Fundamental and Molecular Mechanisms of Mutagenesis, vol. 760, pp. 1-15, 2014.

[6] P. I. Lorenzo and F. Saatcioglu, "Inhibition of apoptosis in prostate cancer cells by androgens is mediated through downregulation of c-jun N-terminal kinase activation," Neoplasia, vol. 10, no. 5, pp. 418-428, 2008.

[7] S. Schleich, M. Papaioannou, A. Baniahmad, and R. Matusch, "Activity-guided isolation of an antiandrogenic compound of pygeum africanum," Planta Medica, vol. 72, no. 06, pp. 547-551, 2006.

[8] M.-E. Taplin, G. J. Bubley, T. D. Shuster et al., "Mutation of the androgen-receptor gene in metastatic androgen-independent prostate cancer," New England Journal of Medicine, vol. 332, no. 21, pp. 1393-1398, 1995.

[9] R. Komakech, Y. Kang, J.-H. Lee, and F. Omujal, “A review of the potential of phytochemicals from prunus africana (hook f.) kalkman stem bark for chemoprevention and chemotherapy of prostate cancer," Evidence-Based Complementary and Alternative Medicine, vol. 2017, Article ID 3014019, 10 pages, 2017.

[10] M. Papaioannou, S. Schleich, D. Roell et al., "NBBS isolated from pygeum africanum bark exhibits androgen antagonistic activity, inhibits AR nuclear translocation and prostate cancer cell growth," Investigational New Drugs, vol. 28, no. 6, pp. 729-743, 2009.

[11] S. Wang, X. Wu, M. Tan et al., "Fighting fire with fire: poisonous Chinese herbal medicine for cancer therapy," Journal of Ethnopharmacology, vol. 140, no. 1, pp. 33-45, 2012.

[12] F.-Z. Chen and X.-K. Zhao, "Prostate cancer: current treatment and prevention strategies," Iranian Red Crescent Medical Journal, vol. 15, no. 4, pp. 279-284, 2013.

[13] T. Gilligan and P. W. Kantoff, "Chemotherapy for prostate cancer," Urology, vol. 60, no. 3, pp. 94-100, 2019.

[14] G. M. Cragg, P. G. Grothaus, and D. J. Newman, "Impact of natural products on developing new anti-cancer agents," Chemical Reviews, vol. 109, no. 7, pp. 3012-3043, 2009.

[15] A. Bhanot, R. Sharma, and M. N. Noolvi, "Natural sources as potential anti-cancer agents: a review," International Journal of Phytomedicine, vol. 3, no. 1, p. 09, 2011.

[16] P. Tugume, E. K. Kakudidi, M. Buyinza et al., "Ethnobotanical survey of medicinal plant species used by communities around mabira central forest reserve, Uganda," Journal of Ethnobiology and Ethnomedicine, vol. 12, no. 1, pp. 5-28, 2016.

[17] O. M. Grace, H. D. V. Prendergast, A. K. Jäger, J. Van Staden, and A. E. van Wyk, "Bark medicines used in traditional healthcare in kwazulu-natal, South Africa: an inventory," South African Journal of Botany, vol. 69, no. 3, pp. 301-363, 2003.

[18] N. S. Shenouda, M. S. Sakla, L. G. Newton et al., "Phytosterol pygeum africanum regulates prostate cancer in vitro and in vivo," Endocrine, vol. 31, no. 1, pp. 72-81, 2007.

[19] S. Tai, Y. Sun, J. M. Squires et al., "PC3 is a cell line characteristic of prostatic small cell carcinoma," The Prostate, vol. 71, no. 15, pp. 1668-1679, 2011.
[20] R. Komakech and Y. Kang, "Ethnopharmacological potential of African cherry [prunus africana]," Journal of Herbal Medicine, vol. 17, Article ID 100283, 2019.

[21] C. A. C. Kadu, A. Parich, S. Schueler et al., "Bioactive constituents in prunus africana: geographical variation throughout Africa and associations with environmental and genetic parameters," Phytochemistry, vol. 83, pp. 70-78, 2022.

[22] A. Cunningham, V. F. Anoncho, and T. Sunderland, "Power, policy and the prunus africana bark trade, 1972-2015," Journal of Ethnopharmacology, vol. 178, pp. 323-333, 2016.

[23] R. Komakech, Y.-G. Kim, W. J. Kim et al., "A micropropagation protocol for the endangered medicinal tree prunus africana (hook f.) kalkman: genetic fidelity and physiological parameter assessment," Frontiers in Plant Science, vol. 11, p. 1871, 2020.

[24] R. Komakech, K.-S. Shim, N.-H. Yim et al., "In vitro antiosteoporosis activity and hepatotoxicity evaluation in zebrafish larvae of bark extracts of prunus jamasakura medicinal plant," Evidence-Based Complementary and Alternative Medicine, vol. 2020, Article ID 8582318, 9 pages, 2020.

[25] P. Davoodpour, M. Bergström, and M. Landström, "Effects of 2-methoxyestradiol on proliferation, apoptosis and PET-tracer uptake in human prostate cancer cell aggregates," Nuclear Medicine and Biology, vol. 31, no. 7, pp. 867-874, 2004.

[26] D. Okello, Y. Chung, H. Kim et al., "Antioxidant activity, polyphenolic content, and FT-NIR analysis of different aspilia africana medicinal plant tissues," Evidence-Based Complementary and Alternative Medicine, vol. 2021, Article ID 9917810, 11 pages, 2021.

[27] D. Okello, S. Yang, R. Komakech et al., "An in vitro propagation of aspilia africana (pers.) CD adams, and evaluation of its anatomy and physiology of acclimatized plants," Frontiers in Plant Science, vol. 12, 2021.

[28] M. Manley, "Near-infrared spectroscopy and hyperspectral imaging: non-destructive analysis of biological materials," Chemical Society Reviews, vol. 43, no. 24, pp. 8200-8214, 2014.

[29] A. De Girolamo, M. Cortese, S. Cervellieri et al., "Tracing the geographical origin of durum wheat by FT-NIR spectroscopy," Foods, vol. 8, no. 10, p. 450, 2019.

[30] F. Murtagh and P. Legendre, "Ward's hierarchical agglomerative clustering method: which algorithms implement ward's criterion?" Journal of Classification, vol. 31, no. 3, pp. 274-295, 2014.

[31] C. Thomas-Charles and H. Fennell, "Anti-prostate cancer activity of plant-derived bioactive compounds: a review," Current Molecular Biology Reports, vol. 5, no. 3, pp. 140-151, 2017.

[32] R. L. von Holtz, C. S. Fink, and A. B. Awad, “ $\beta$-sitosterol activates the sphingomyelin cycle and induces apoptosis in LNCaP human prostate cancer cells," Nutrition and Cancer, vol. 32, no. 1, 1998.

[33] A. B. Awad, Y. Gan, and C. S. Fink, "Effect of $\beta$-sitosterol, a plant sterol, on growth, protein phosphatase $2 \mathrm{~A}$, and phospholipase D in LNCaP cells," Nutrition and Cancer, vol. 36, no. 1, pp. 74-78, 2000.

[34] J. O. Ban, I. G. Hwang, T. M. Kim et al., "Anti-proliferate and pro-apoptotic effects of 2, 3-dihydro-3, 5-dihydroxy-6methyl-4H-pyranone through inactivation of NF- $\kappa \mathrm{B}$ in human colon cancer cells," Archives of Pharmacal Research, vol. 30, no. 11, pp. 1455-1463, 2007.

[35] H. A. Ganaie, M. N. Ali, B. A. Ganai, and S. Bashir, "Antimutagenic activity of compounds isolated from ajuga bracteosa wall ex. benth against EMS induced mutagenicity in mice," Toxicology Reports, vol. 5, pp. 108-112, 2017. 
[36] P. G. Anantharaju, B. D. Reddy, M. A. Padukudru, C. M. Kumari Chitturi, M. G. Vimalambike, and S. V. Madhunapantula, "Naturally occurring benzoic acid derivatives retard cancer cell growth by inhibiting histone deacetylases (HDAC)," Cancer Biology \& Therapy, vol. 18, no. 7, pp. 492-504, 2017.

[37] A. M. Rieger, K. L. Nelson, J. D. Konowalchuk, and D. R. Barreda, "Modified annexin V/propidium iodide apoptosis assay for accurate assessment of cell death," JoVE (Journal of Visualized Experiments), vol. 50, Article ID e2597, 2011.

[38] H. M. Hankins, R. D. Baldridge, P. Xu, and T. R. Graham, "Role of flippases, scramblases and transfer proteins in phosphatidylserine subcellular distribution," Traffic, vol. 16, no. 1, pp. 35-47, 2015.

[39] K. Segawa and S. Nagata, "An apoptotic "eat me"signal: phosphatidylserine exposure," Trends in Cell Biology, vol. 25, no. 11, pp. 639-650, 2015.

[40] W. G. Telford, A. Komoriya, B. Z. Packard, and C. B. Bagwell, "Multiparametric analysis of apoptosis by flow cytometry," in Flow Cytometry Protocols, pp. 203-227, Springer, Berlin, Germany, 2011.

[41] N. Atale, S. Gupta, U. C. S. Yadav, and V. Rani, "Cell-death assessment by fluorescent and nonfluorescent cytosolic and nuclear staining techniques," Journal of Microscopy, vol. 255, no. 1, pp. 7-19, 2014.

[42] F. Wallberg, T. Tenev, and P. Meier, "Analysis of apoptosis and necroptosis by fluorescence-activated cell sorting," Cold Spring Harbor Protocols, vol. 2016, no. 4, Article ID pdb., 2016.

[43] T. Afsar, J. H. Trembley, C. E. Salomon, S. Razak, M. R. Khan, and K. Ahmed, "Growth inhibition and apoptosis in cancer cells induced by polyphenolic compounds of acacia hydaspica: involvement of multiple signal transduction pathways," Scientific Reports, vol. 6, no. 1, Article ID 23077, 2016.

[44] M. A. Rahman and J. Akhtar, "Evaluation of anticancer activity of cordia dichotoma leaves against a human prostate carcinoma cell line, PC3," Journal of Traditional and Complementary Medicine, vol. 7, no. 3, pp. 315-321, 2017.

[45] M. J. Onyancha, Evaluation of Antibreast and Antiprostate Cancer Activities of Selected Medicinal Plants From Some Parts of Kenya, Kenyatta University, Nairobi, Kenya, 2019.

[46] S. C. Ghagane, S. I. Puranik, V. M. Kumbar et al., "In vitro antioxidant and anticancer activity of leea indica leaf extracts on human prostate cancer cell lines," Integrative Medicine Research, vol. 6, no. 1, pp. 79-87, 2017.

[47] O. Yesil-Celiktas, C. Sevimli, E. Bedir, and F. Vardar-Sukan, "Inhibitory effects of rosemary extracts, carnosic acid and rosmarinic acid on the growth of various human cancer cell lines," Plant foods for Human Nutrition, vol. 65, no. 2, pp. 158-163, 2010.

[48] A.-H. Xu, Z.-M. Hu, J.-B. Qu et al., "Cyclic bisbibenzyls induce growth arrest and apoptosis of human prostate cancer PC3 cells," Acta Pharmacologica Sinica, vol. 31, no. 5, pp. 609-615, 2010.

[49] M. Nachshon-Kedmi, S. Yannai, and F. A. Fares, "Induction of apoptosis in human prostate cancer cell line, PC3, by $3,3^{\prime}$ diindolylmethane through the mitochondrial pathway," British Journal of Cancer, vol. 91, no. 7, pp. 1358-1363, 2004. 